\title{
炭素/炭化ケイ素複合材料の摩擦・摩耗特性
}

\author{
外尾道太・佐々木 寛・広中清一郎 \\ 東京工業大学工学部無機材料工学科, 152-8552 東京都目黒区大岡山 2-12-1
}

\section{Friction and Wear Properties of Carbon/Silicon Carbide Composites}

Michita HOKAO, Hiroshi SASAKI and Seiichiro HIRONAKA

Department of Inorganic Materials, Faculty of Engineering, Tokyo Institute of Technology, 2-12-1, Ookayama, Meguro-ku, Tokyo

\begin{abstract}
This paper describes the friction and wear properties of carbon/silicon carbide composites in comparison with that of porous silicon carbide and dense silicon carbide. Tests were conducted in ambient air, using a pin-on-disk friction test apparatus. The friction and wear properties of these materials varied according to the combination of pin and disk materials. The carbon/silicon carbide composite containing the largest carbon volume (about $40 \mathrm{vol} \%$ ) showed the lowest values of îriction coefficient and specific wear among all the investigated materials. In addition, it also showed a stable behavior with respect to sliding velocity. The friction and wear mechanisms of these materials were discussed according to the morphology of the worn surfaces observed by scanning electron microscopy (SEM).
\end{abstract}

Key-words : SiC, Carbon, Composites, Friction, Wear

\section{1. 緒 言}

セラミックスは一般に, 高強度, 高硬度, 高融点, 耐腐食 性，耐摩耗性など優れた特性を有する。このため金属や高分子 材料に代わる描動材料として, 特に極低温, 超高温, 超真空, 腐食性䨌囲気などの極限条件における適用が期待されている。 このような極限条件においては，流動性の低下，熱・酸化劣 化，蒸発などのために潤滑油の適用は難しいため，十分なトラ イボロジ一特性を持つ無給油型のトライボセラミックスの開発 が要求されている。この解決法の一つとして, 潤滑性を有する 材料と複合化することにより，自己潤滑性を有するセラミック 天系複合材料の開発がなされている1) 6).

炭化ケイ素はセラミックスの中において低摩擦・低摩耗を示 すトライボ材料として知られ7) - 8), 特に水中に扔いては優れ た摩擦・摩耗特性が得られている ${ }^{9)}$ 10)。著者らは自己潤滑性 を有する炭化ケイ素複合材料として, 多孔質炭化ケイ素に, 潤 滑性を有する低蒸気圧性のパーフルオロポリエーテルを複合さ せた複合材料の摩擦・摩耗特性 (1) 3) や, グラファイトを摩擦 充媜した複合材料の摩擦・摩耗特性 ${ }^{4}$ を無潤滑条件におけて研 究し, 良好な結果を得ている。

本研究では, 多孔質炭化ケイ素に炭素を複合させた複合材料 を調製し, ピン/ディスク型摩擦試験機を用いて滑り速度及び ピン/ディスクの試験片の組み合わせを変えて摩擦試験を行っ た. 炭素材料は潤滑性, 耐熱性及び耐食性などの優れた特性を 有する11) 12)ため，炭化ケイ素と複合化することにより優れた 潤滑性が付与されることが期待される。潤滑性試験片表面の走
査型電子顕微鏡 $(\mathrm{SEM})$ 観察を行い, 得られたモルホロジー から摩擦・摩耗機構を考察した。

\section{2. 実 験}

\section{1 試料の調製}

炭化ケイ素試料は, $\mathrm{SiC}$ 粉末（純度 $99 \%$ 以上, 平均粒径 0.3 $\mu \mathrm{m})$ を原料とし, 焼結助剂として $\mathrm{B}_{4} \mathrm{C}$ 粉末及びカーボンを用 いて調製した。緻密質の $\mathrm{SiC} は 2100^{\circ} \mathrm{C}$, 多孔質の $\mathrm{SiC}$ は $1950^{\circ} \mathrm{C}$ で不活性ガス雾囲気中において焼結した。X線回折よ 、り, 調製したこれらの炭化ケイ素は $\alpha-\mathrm{SiC}$ 及び $\beta$-SiC の混在体 之同定された。

炭素/炭化ケイ素複合材料は, 有機系炭素を減圧下で多孔質 炭化ケイ素に含浸させ, 不活性ガス雲囲気中, $500 \sim 600^{\circ} \mathrm{C} て ゙$ 加熱炭化処理を行うことにより調製した，炭素を十分含浸させ るためにこの操作を 2 回行った。 ディスク試料はエメリ一紙 （\#600１000）で研磨した。各試験試料は，トルエン及びアセ トン中でそれぞれ $15 \mathrm{~min}$ 超音波洗浄を行い, 乾燥器中で十分 に乾燥した後, 試験に供した。

\section{2 試験試料}

試験試料は緻密質炭化ケイ素 (以下, (緻密質) SiC と略す), 気孔率15２0\%と 40４5\%の多孔質炭化ケイ素（以下，それ ぞれ $\mathrm{SiC} 20$ 及び $\mathrm{SiC} 45$ と略す) 及びそれぞれの炭素/炭化ケイ 素複合材料（以下，それぞれ $\mathrm{SiC} 20 \mathrm{C}$ 及び $\mathrm{SiC} 45 \mathrm{C}$ 上略す）を 用いた。末含浸炭化ケイ素試料の主な物性值を表 1 に示す。 そ れぞれの試料は, 半球ピン（曲率半径 $13.5 \mathrm{~mm}$, 長さ 10.0

Table 1. Physical Properties of the Silicon Carbides

\begin{tabular}{|c|c|c|c|}
\hline Sample & $\mathrm{SiC}$ & $\mathrm{SiC20}$ & $\mathrm{SiC45}$ \\
\hline Porosity /\% & $<4$ & $15-20$ & $40-45$ \\
\hline Apparent density $/ 10^{3} \mathrm{~kg} \mathrm{~m}^{-3}$ & 3.1 & 2.7 & 1.8-1.9 \\
\hline Vickers hardness / HV & 3100 & - & 300 \\
\hline Young's modulus / GPa & 390 & 290 & $91-130$ \\
\hline Bending strength / $\mathbf{M P a}$ & 810 & 520 & $150-200$ \\
\hline Fracture toughness $/ \mathrm{MPa} \cdot \mathrm{m}^{1 / 2}$ & 3.5 & 3.5 & - \\
\hline Thermal conductivity $/ \mathbf{W} \cdot \mathbf{m}^{-1} \cdot \mathbf{K}^{-1}$ & 79 & 46 & 29-33 \\
\hline Specific heat $/ \mathbf{J} \cdot \mathrm{kg}^{-1} \cdot \mathbf{K}^{-1}$ & 790 & 460 & $880-960$ \\
\hline
\end{tabular}


Table 2. Friction Test Conditions

\begin{tabular}{cccl}
\hline Sliding velocity $/ \mathrm{m} \mathrm{s}^{-1}$ & Load $/ \mathrm{N}$ & Sliding distance $/ \mathrm{m}$ & \multicolumn{1}{c}{ Atmosphere } \\
\hline $0.2,0.75,1.5$ & 4.9 & $1.6 \times 10^{4}$ & $\begin{array}{l}\text { Ambient air } \\
\text { Room temperature } \\
\text { Relative humidity: } 40-60 \%\end{array}$ \\
\hline
\end{tabular}

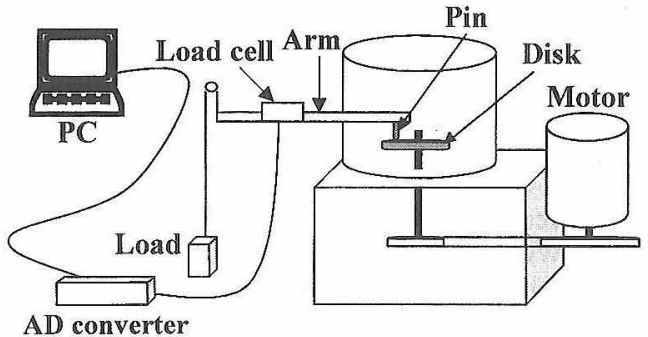

Fig. 1. Sketch of the pin/disk type friction test apparatus.

$\mathrm{mm}$ ）及びディスク（外径 $55 \mathrm{~mm}$, 内径 $10 \mathrm{~mm}$, 厚さ $5 \mathrm{~mm}$ ) として加工した.

\section{3 摩擦試験}

摩擦試験は同種類のピン及びディスクを用いた場合，及び $\mathrm{SiC}$ ピンに対して各種ディスク試料を摩擦した場合に扔いて, 滑り速度を变化させた条件 $\left(0.2 \mathrm{~ms}^{-1}, 0.75 \mathrm{~ms}^{-1}, 1.5 \mathrm{~ms}^{-1}\right)$ で行い，摩擦係数と摩耗量を測定した．表 2 に試験条件を示 す、試験装置はピン/ディスク型試験機を用いた（図 1)。この 装置ではピンとディスクを滑り摩擦させたときの摩擦力がロー ドセルによって測定される. 得られた摩擦力は $\mathrm{AD}$ 変換器を 通して摩擦係数として記録された．滑り速度はディスクの回転 数を変化させることで調節し，荷重はアームを通してピン側か らかかる. 摩擦試験開始直後から試験終了屯での摩擦係数值を 平均した值を平均摩擦保数とした。

摩擦試験後, 光学顕微鏡及び表面粗さ計によってピン試料の 平均摩耗半径及びディスク試料の摩耗断面図をそれぞれ測定し た。これらよりピン及びディスクの摩耗体積を算出した。単位 当たりの滑り距離及び荷重に対するピンとディスクの総摩耗体 積を比摩耗量 $\left(\mathrm{mm}^{3} \mathrm{~N}^{-1} \mathrm{~m}^{-1}\right)$ として求め, 摩耗特性老検討 した。

試験後に走査型電子顕微鏡（SEM; JSM, T-220A）を用い て摩擦表面のモルホロジー観察を行った。

\section{1 摩擦係数}

\section{3. 結果及び考察}

図 2 に，同じ種類のピン及びディスクを滑り速度 $0.75 \mathrm{~ms}^{-1}$ で滑り摩擦させた場合の摩擦係数の経時変化を示す。気孔率の 異なる複合化していない $\mathrm{SiC}$ 試料の摩擦係数を比較すると, 気孔率の増加とともに摩擦係数の上昇及び摩擦係数の変動幅の 增加が見られ，緻密質 $\mathrm{SiC} に$ 打いて摩擦係数がより小さく， 比較的変動の少ない摩擦特性が得られた. 気孔率の变化による これらの摩擦特性の相違は，摩擦せん断に対する強度の差が反 映しているものと考えられ， $\mathrm{SiC} 45$ では脆性破壊が著しく，こ れが摩擦係数の不安定さと上昇に影響したものと考えられる。 $\mathrm{SiC}$ 系においては滑り距離の増加とともに摩擦係数が上昇傾向 を示したのに対して ${ }^{3)}$ ，SiC45 系に扔いては摩擦後半で多少の 摩擦係数の低減が観察され, 滑り距離の増加とともに摩擦係数 値の変動が小さくなる傾向を示した。これは SiC45 の開気孔

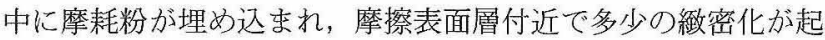
こったものと推諭される，炭素複合 $\mathrm{SiC}$ 系におおては，炭素
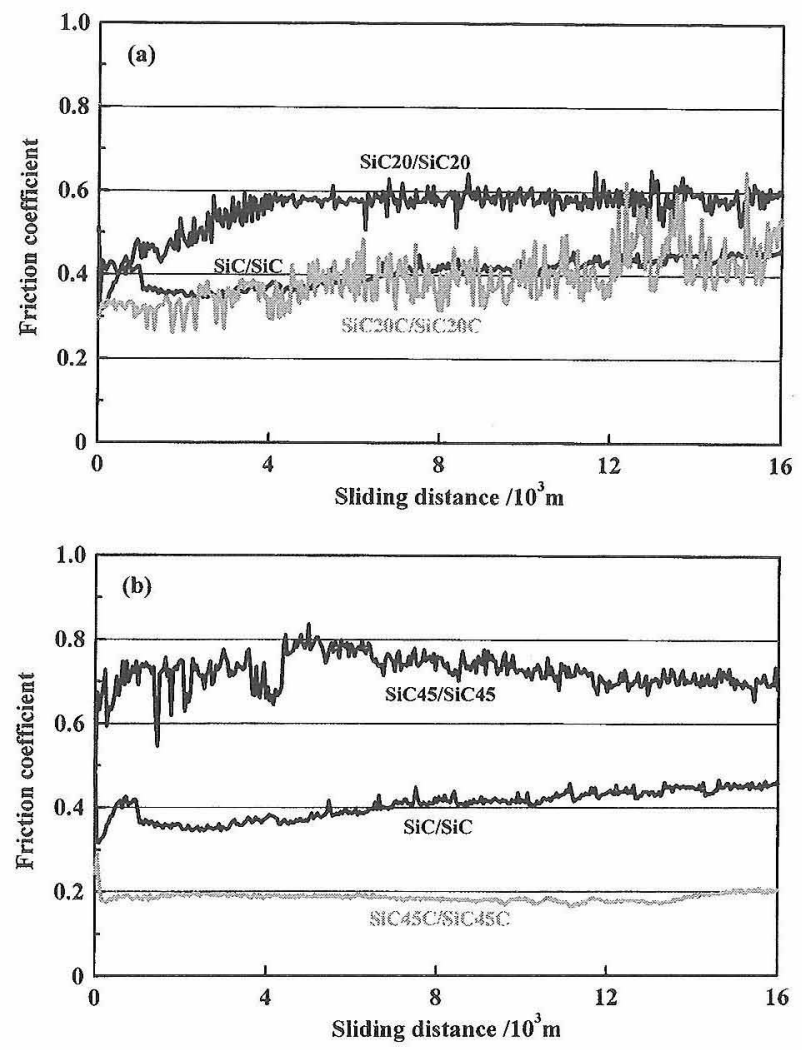

Fig. 2. Friction coefficient as a function of sliding distance in the self-mated silicon carbides and their composites at sliding velocity of $0.75 \mathrm{~ms}^{-1}$; (a) $\mathrm{SiC}, \mathrm{SiC} 20$ and $\mathrm{SiC} 20 \mathrm{C}$ systems and (b) SiC, $\mathrm{SiC} 45$ and $\mathrm{SiC} 45 \mathrm{C}$ systems.

含有量の最も多い $\mathrm{SiC} 45 \mathrm{C}$ 系で非常に摩擦係数の小さい，しか も安定した摩擦特性が得られた。これは含浸された炭素が固体 潤滑剂11)として十分に潤滑作用したためと考えられ，この 安定した低摩擦係数は油含浸効果と同等以上の効果であっ $た^{1) \sim 3)}$.これに対して $\mathrm{SiC} 20 \mathrm{C}$ 系では炭素の含有量が不十分で あるためか，炭素の複合化効果ははとんど得られず，摩擦係数 值は緻密質 SiC とほぼ同じであったが，摩擦係数の变動はむ しろ大きかった。

図 3 として，同じ材質同士に抢ける，平均摩擦係数の滑り速 度による变化を示す. $\mathrm{SiC} 45 \mathrm{C}$ 系を除いては, 滑り速度の増加 之ともに平均摩擦係数も上昇して扣り, 平均摩擦係数に速度依 存性が見られた。これに対して $\mathrm{SiC} 45 \mathrm{C}$ 系においては滑り速度 によらずほぼ一定のより小さい平均摩擦係数が得られ，滑り速 度に対して安定した摩擦係数を示した。炭素無充填の $\mathrm{SiC}$ 試 料における平均摩擦係数を比較すると, 各滑り速度において気 孔率の増加とともにより高い平均摩擦係数を示したが，炭素を 複合することにより摩擦係数の著しい低下が見られ，特に $\mathrm{SiC} 45 \mathrm{C}$ 系に抢いてより顕著であった。滑り速度 $0.2 \mathrm{~ms}^{-1}$ の 低速度においては各試料の平均摩擦係数の差が 0.2 以内に収 まっているのに詨して, 速度が上昇すると, 各試料の平均摩擦 係数の差が増大し, 試料による摩擦係数の違いが明確にあらわ れた。 


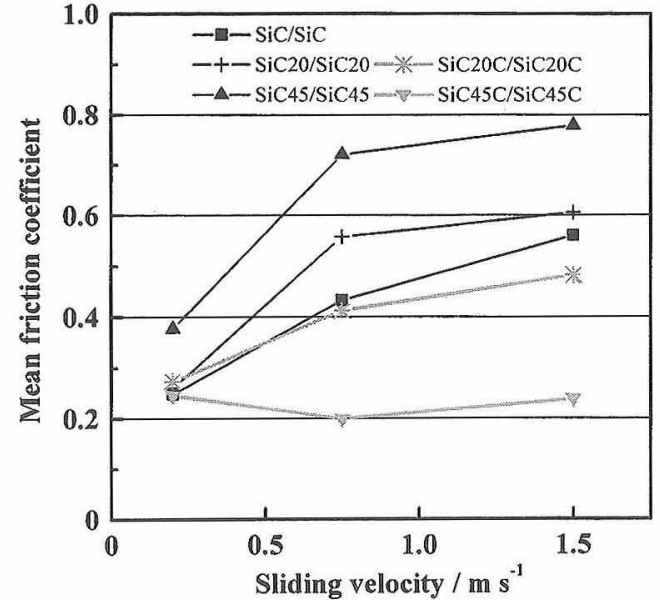

Fig. 3. Sliding velocity dependence of mean friction coefficient in the self-mated silicon carbides and their composites.
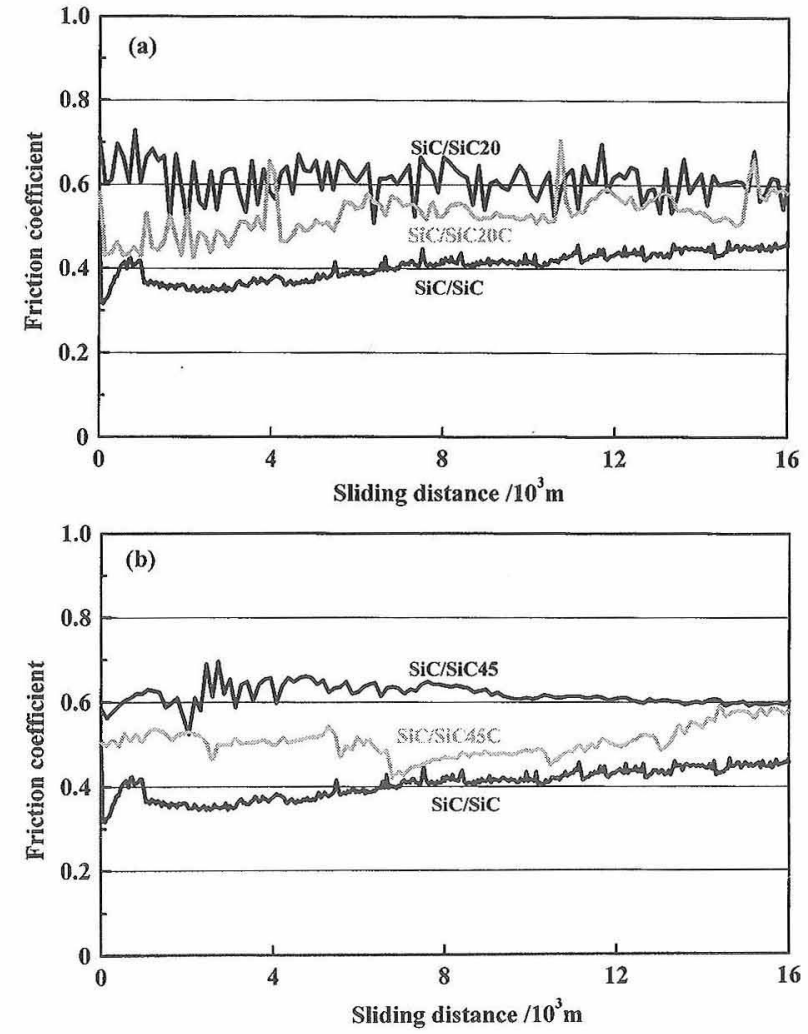

Fig. 4. Friction coefficient as a function of sliding distance in the system of dense silicon carbide/silicon carbides and their composites at sliding velocity of $0.75 \mathrm{~ms}^{-1}$; (a) $\mathrm{SiC}, \mathrm{SiC} 20$ and $\mathrm{SiC} 20 \mathrm{C}$ systems and (b) $\mathrm{SiC}, \mathrm{SiC} 45$ and $\mathrm{SiC} 45 \mathrm{C}$ systems.

炭素無充填の $\mathrm{SiC}$ 試料に括ける, 気孔率の増大による摩擦 係数の上昇の原因には, 気孔率の増大に伴う強度及び硬度の低 下及び真実接触面積の減少による接触圧力の上昇が考えられ， このため気孔率の大きいものはど摩擦せん断による脆性破壊が 大きく, これが摩擦係数の増大に大きく関係するものと考元ら れる，また，滑り速度の増大により摩擦係数が大きく増加した が，これは速度の上昇により摩擦界面における熱的，機械的条 件が厳しくなったためであると考えられる。

多孔質 $\mathrm{SiC}$ 炭素と複合材化することにより摩擦係数の低 下が見られた。一般に炭素材料は良好な潤滑性を有することが

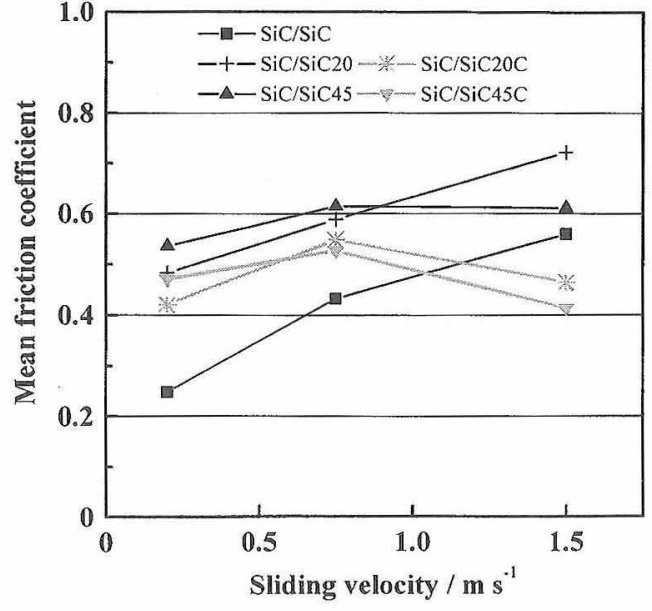

Fig. 5. Sliding velocity dependence of mean friction coefficient in the system of dense silicon carbide/silicon carbides and their composites.

知られており，この炭素の潤滑作用と併せて，炭素との複合材 化により多孔質 $\mathrm{SiC} の$ 表面は平滑化され, 摩擦係数が低下し たと考えられる。炭素含有 $\mathrm{SiC}$ 系では, $\mathrm{SiC} 45 \mathrm{C}$ 系において低 く, 安定した摩擦挙動が得られたこれは炭素含有量のより多 いSiC45Cにおいては炭素による十分な潤滑効果が得られたた めであると考えられる。

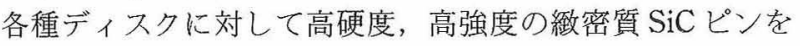
摩擦させた場合の摩擦特性を図 4 に示す. 高度, 強度に劣る多 孔質 $\mathrm{SiC}$ ディスク系では，緻密質 $\mathrm{SiC}$ 同士系に比較して約 1.5 倍の高い摩擦係数を示した.これらの多孔質 $\mathrm{SiC}$ は炭素充填 することによって摩擦係数が多少低下したが, 緻密質 $\mathrm{SiC}$ 同 士系のレベルまでは低減されなかった，この理由として，炭素 複合 $\mathrm{SiC} テ ゙ ィ ス ク$ 平面に対してより高硬度, 高強度でしかも 曲率の小さい緻密質ピンを滑り摩擦させるという厳しい条件で めるために，充填された炭素による潤滑作用がこれらの特性差 を補うことが出来なかったものと考光られる。おそらく平面同 士の接触圧の低いマイルドな摩擦条件ではより良い摩擦特性が 得られるものと考えられ，今後検討したい．

図 5 に，緻密質 $\mathrm{SiC}$ ピンに対して各ディスクを摩擦させた ときの, 滑り速度による平均摩擦係数の变化を示す. $\mathrm{SiC} / \mathrm{SiC}$ 及び $\mathrm{SiC} / \mathrm{SiC} 20$ 系においては平均摩擦係数に明確な速度依存 性が見られたが，他の組久合わせに扔いては速度依存性はほと んど見られなかった. $\mathrm{SiC} / \mathrm{SiC} 20$ 及び $\mathrm{SiC} / \mathrm{SiC} 45$ 系に対して ディスクに炭素を含有した $\mathrm{SiC} / \mathrm{SiC} 20 \mathrm{C}$ 及び $\mathrm{SiC} / \mathrm{SiC} 45 \mathrm{C}$ 系で はそれぞれ炭素の潤滑効果により小さい摩擦係数が得られ，特 に高速度の $1.5 \mathrm{~ms}^{-1}$ で顕著であった。炭素含有複合材同士の 摩擦である $\mathrm{SiC} 20 \mathrm{C} / \mathrm{SiC} 20 \mathrm{C}$ 及び $\mathrm{SiC} 45 \mathrm{C} / \mathrm{SiC} 45 \mathrm{C}$ 系に比較し て, 一方に緻密質の $\mathrm{SiC}$ を用いると, 摩擦係数の大きな上昇 を示した．この原因として, 緻密質 $\mathrm{SiC}$ は多孔質 $\mathrm{SiC}$ を材 とする炭素含有複合材と比較して強度及び硬度に優れるため,

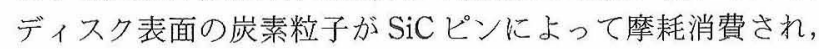
炭素による潤滑効果が低減したためであると考えられる.

\section{2 比摩耗量}

図 6 に同種のピン/ディスク系における，滑り速度に対する 比摩耗量の変化を示す。 $\mathrm{SiC} 45 \mathrm{C} / \mathrm{SiC} 45 \mathrm{C}$ 系を除いた系におい ては滑り速度の増加とともに比摩耗量も増加しており, 速度依 存性が見られる。特に $\mathrm{SiC} 20$ 系においては $0.75 \mathrm{~ms}^{-1}$ から $1.5 \mathrm{~ms}^{-1}$ にかけて比摩耗量の大幅な増加がみられた。速度の 


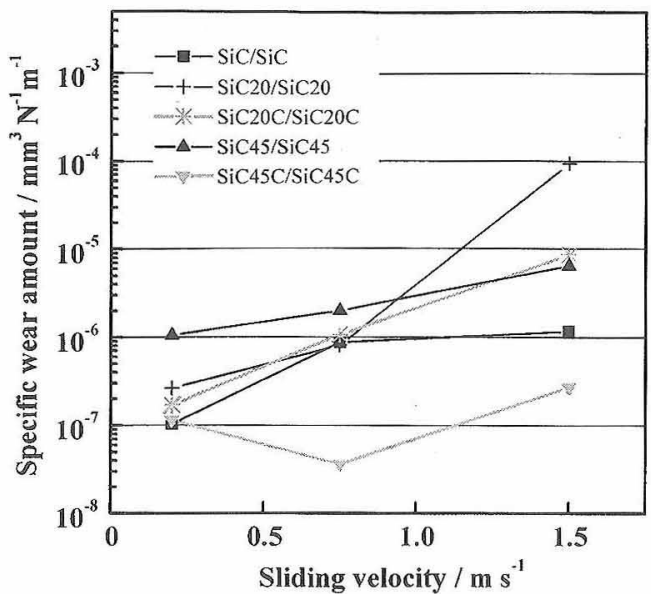

Fig. 6. Sliding velocity dependence of specific wear amount in the self-mated silicon carbides and their composites.

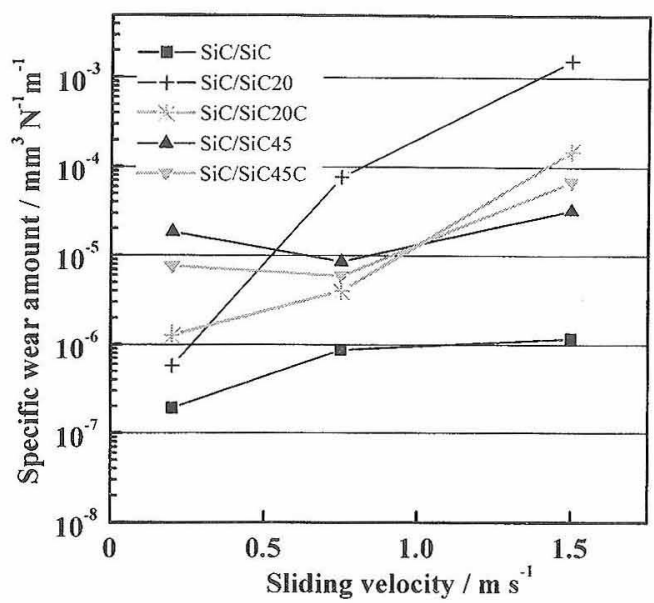

Fig. 7. Sliding velocity dependence of specific wear amount in the system of silicon carbide/silicon carbides and their composites.

上昇による比摩耗量には, 摩擦界面における熱的, 機械的条件 の悪化が関係している考えられる． SiC $45 / \mathrm{SiC} 45$ 系が多孔質 系にもかかわらず，予想外に比摩耗量が少ない理由としては摩 耗粉の一部が気孔に埋なったことが考えられる。一方， $\mathrm{SiC} 45 \mathrm{C}$ 系においては $10^{-8} \sim 10^{-7} \mathrm{~mm}^{3} \mathrm{~N}^{-1} \mathrm{~m}^{-1}$ の非常に低い 比摩耗量が得られ，摩擦挙動と摩耗挙動が良く対応していた。 このことからある程度以上の炭素を含む $\mathrm{SiC}$ 複合材料同士の 滑り摩擦では, 無給油型の摩擦・摩耗特性に優れるトライボロ ジー系が得られることが分かった。

図 7 に, SiCピンに対して各種ディスクを滑らせた場合の, 比摩耗量の滑り速度依存性を示す。ディスクに炭素/炭化ケィ 素複合材料を用いた $\mathrm{SiC} / \mathrm{SiC} 20 \mathrm{C}$ や $\mathrm{SiC} / \mathrm{SiC} 45 \mathrm{C}$ 系でも耐摩耗 特性の向上は認められず, $\mathrm{SiC} / \mathrm{SiC}$ 系が最も低い比摩耗量を示

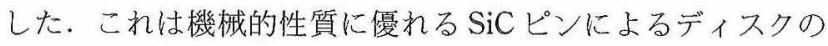
掘り起しし作用のために, 摩耗が増大したためであると考えら

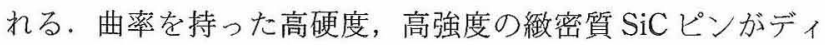
スク平面に対して負荷接触しているため, 接触部の接触圧はか なり高いことが推測され，このため掘り起こしが生ずるものと 考えられる.

\section{3 ディスク摩耗表面の SEM 観察}

図 8 から図10に，摩擦試験前後の各系における $\mathrm{SiC}, \mathrm{SiC} 45$,
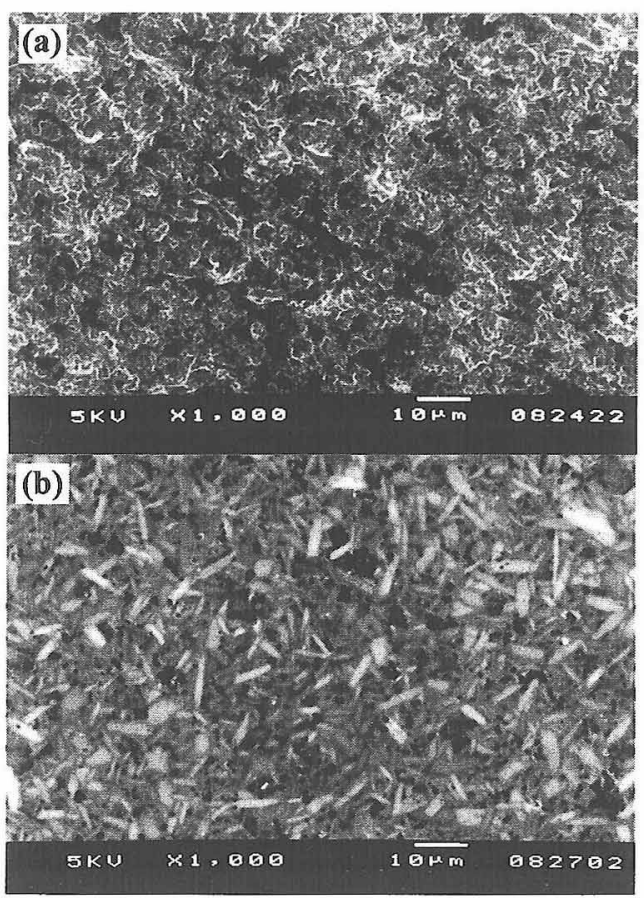

Fig. 8. SEM photographs of the unworn area (a) and worn area (b) of the $\mathrm{SiC}$ disk in the $\mathrm{SiC} / \mathrm{SiC}$ system at $1.5 \mathrm{~ms}^{-1}$.

$\mathrm{SiC} 45 \mathrm{C}$ ディスク試料の SEM 写真を示す. 図 8 に示すように, $\mathrm{SiC}$ ディスクの摩耗面はランダムに配向した棒状物質に覆われ ており，試験前と異なるモルホロジーが得られた．この棒状物 質は $\alpha$-SiC 結晶と考えられ, 滑り摩擦により初期の表面層が取 り除かれたため現れたものと考えられる．多孔質 SiC を代表 して SiC45 ディスクの SEM 写真を図 9 に示す. SiC45 の試験 前の表面では開気孔が多数見られた（図 9(a)）のに対して, 摩擦試験後の表面では試験前に゙見られたような開気孔はほとん ど見られず，より荒れた状態になっていた（図 9(b)及び(c)). $\mathrm{SiC} 45$ 同土で滑らせた場合には摩耗面中に表面がめくれあがっ たような部分が散見された（図9(b)）のに対して, 緻密質 $\mathrm{SiC}$ ピンに対して摩擦させた場合には頂上部が上から押し固め られたような形状を持つ小丘部が摩耗面中に多数見られ（図 $9(\mathrm{c}))$, SiC45 同士の場合よりもむしろ摩耗面は平滑化されて

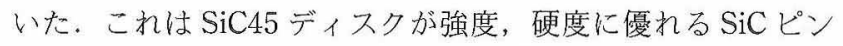
によって掘り起こされたためであると考えられる. SiC20 ディ スクでは SiC45 ディスクと同様な摩耗面が得られたが, 気孔 率が低いためか摩耗面はより平滑化されていた，炭素/炭化ケ イ素複合材を代表して SiC45C の SEM 写真を図10に示す. SiC45C の試験前の表面は炭素複合化により多少繳密化が見ら れるものの SiC45 と同様な凹凸の多い粗いモルホロジーを示 した（図10(a)). 摩擦試験後の $\mathrm{SiC} 45 \mathrm{C}$ ディスクでは, ピンに $\mathrm{SiC} 45 \mathrm{C}$ 及び繳密質 $\mathrm{SiC}$ を用いたそれぞれの場合において $\mathrm{SiC} 45$ ディスクでは見られなかった平滑な摩耗面が得られた (図10(b)及び (c)).このような平滑な摩耗面は, 炭素充填に よる試料の緻密化及び炭素固有の潤滑性のために形成されたと 考えられる. 特に SiC45C 同士を滑らせた系においては, 摩擦 界面に十分な量の炭素が供給されるためか非常に平滑な摩耗面 が得られ, 本研究により得られた摩擦・摩耗特性とよく対応し ていた. SiC20Cディスクでは SiC45Cディスクと同様な傾向 を示したが，炭素の含有量がより多い $\mathrm{SiC} 45 \mathrm{C}$ を用いた場合よ りも荒れた摩耗面を示した。 


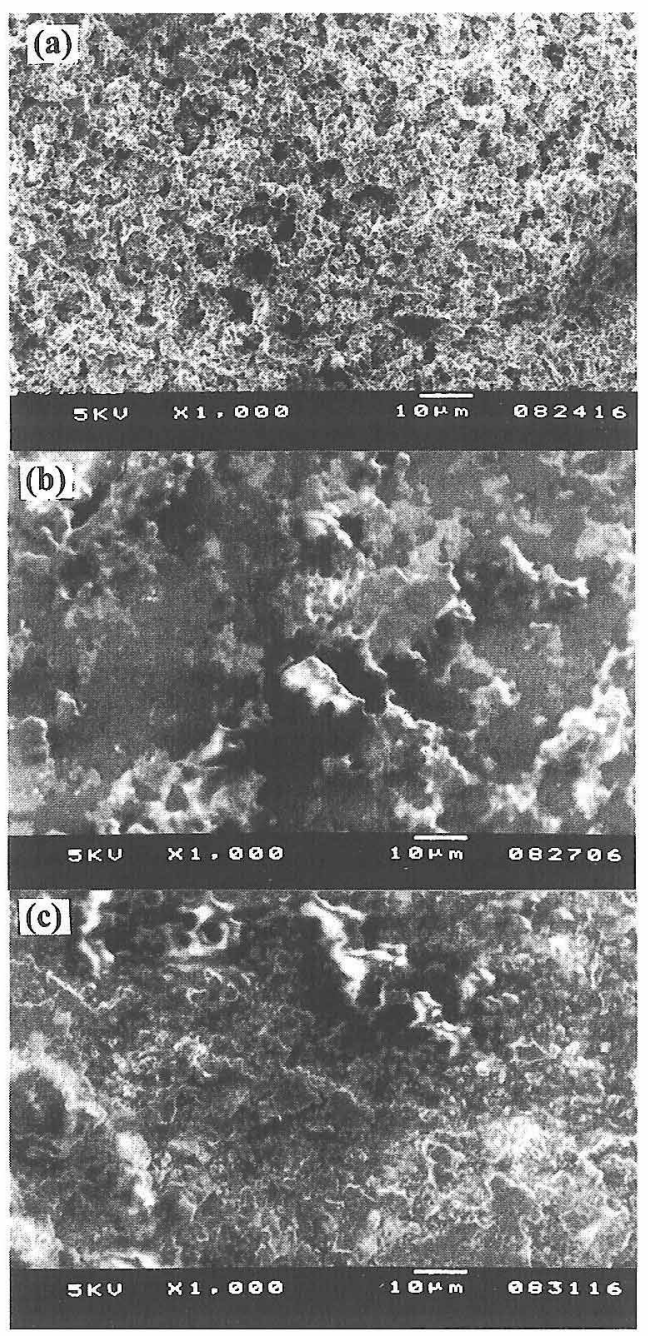

Fig. 9. SEM photographs of the unworn area (a) and worn areas of the $\mathrm{SiC} 45$ disks in the $\mathrm{SiC} 45 / \mathrm{SiC} 45$ system (b) and $\mathrm{SiC} / \mathrm{SiC} 45$ system (c) at $1.5 \mathrm{~ms}^{-1}$.

\section{4. 結 言}

本研究では, 緻密質 $\mathrm{SiC}$, 気孔率の異なる多孔質 $\mathrm{SiC}$ ( $\mathrm{SiC} 20$ 及び $\mathrm{SiC} 45)$ 及びこれらの多孔質 $\mathrm{SiC}$ に炭素を含浸・暁成し た炭素/炭化ケイ素複合材（SiC20C 及び $\mathrm{SiC} 45 \mathrm{C}$ ) を用いて， その摩擦・摩耗特性を無潤滑下に扔いて比較検討した。

同種のピン及びディスクを用いて摩擦試験を行った場合，気 孔率40４5\%の多孔質 $\mathrm{SiC}$ に炭素を含浸させた $\mathrm{SiC} 45 \mathrm{C} /$ $\mathrm{SiC} 45 \mathrm{C}$ 系に拈いて，最も低い経時安定性のある摩擦係数及び 比摩耗量を示し，かつ速度依存性のない優れた摩擦・摩耗特性 が得られた．これは摩擦界面に十分に存在する炭素が潤滑作用 を示したためであると考えられ，炭素/炭化ケイ素複合材のト ライボ材料としての可能性が示された。これに対して, 故密質 $\mathrm{SiC} ヒ ゚ ン に$ 対して各ディスク試料を摩擦させた場合，多孔質 $\mathrm{SiC}$ に炭素を複合させることにより摩擦係数が低下したが， $\mathrm{SiC} / \mathrm{SiC}$ 系におけるほどの低い比摩耗量は得られなかった。こ れは緻密質 $\mathrm{SiC}$ が高硬度, 高強度の機械的特性に優れている ためであると考えられる。これらの結果は摩擦界面での接触圧 の高いピン/ディスク型試験によるものであり, 面接触のよう なより接触圧の低い条件では炭素による潤滑効果がより効果的 に得られると考えられるため，今後の倹討課題としたい。

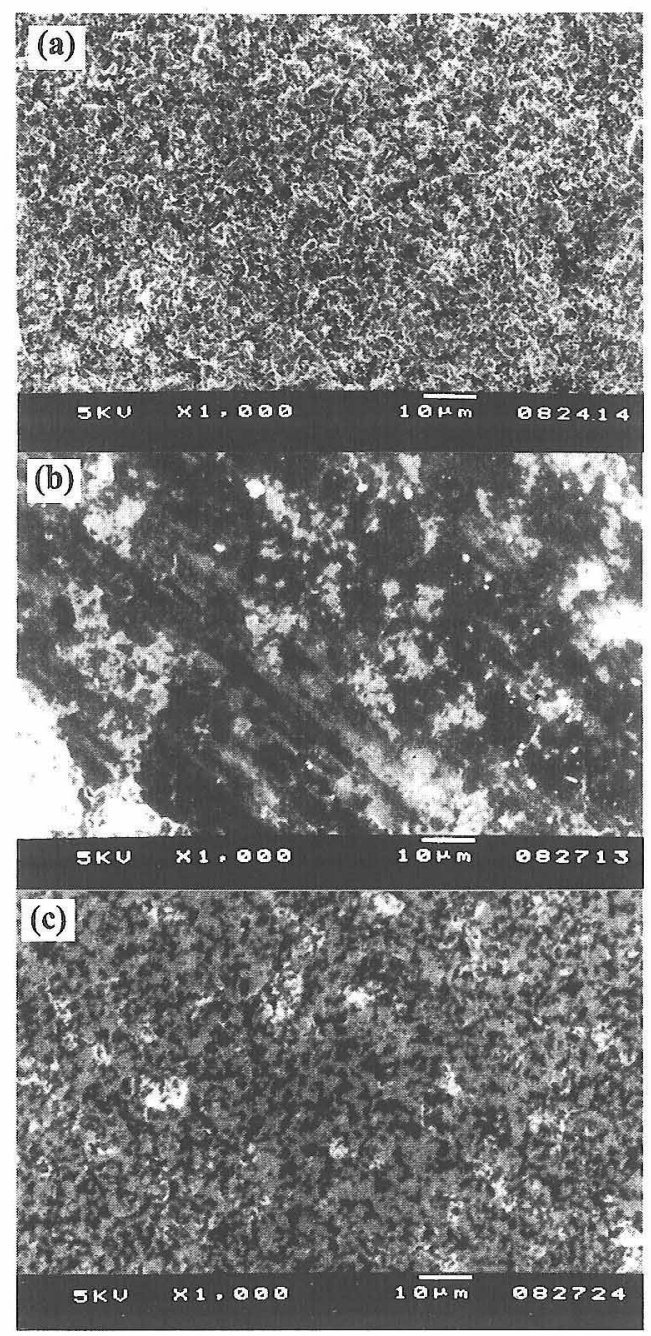

Fig. 10. SEM photographs of the unworn area (a) and worn areas of the $\mathrm{SiC} 45 \mathrm{C}$ disks in the $\mathrm{SiC} 45 \mathrm{C} / \mathrm{SiC} 45 \mathrm{C}$ system (b) and $\mathrm{SiC} / \mathrm{SiC} 45 \mathrm{C}$ system (c) at $1.5 \mathrm{~ms}^{-1}$.

\section{文 献}

1) T. Jimbo and S. Hironaka, J. Ceram. Soc. Japan, 104, 620-25 (1996) [in Japanese].

2) T. Jimbo and S. Hironaka, the 1st World Tribology Congress, London (1997) p. 137.

3) T. Jimbo and S. Hironaka, J. Ceram. Soc. Japan, 105, 492-95 (1997).

4) T. Jimbo and S. Hironaka, Mater. Technol., 15, 248-51 (1997) [in Japanese].

5) M. Iwasa and S. Kakiuchi, J. Ceram. Soc. Japan (YogyoKyokai-Shi), 93, 661-65 (1985) [in Japanese].

6) M. Iwasa and Y. Nagai, J. Ceram. Soc. Japan (Yogyo-KyokaiShi), 95, 1202-06 (1987) [in Japanese].

7) M. Iwasa and Y. Toibana, J. Ceram. Soc. Japan (YogyoKyokai-Shi), 94, 336-43 (1986) [in Japanese].

8) J. Denape and J. Lamon, J. Mater. Sci., 25, 3592-604 (1990).

9) B. Loffelbein and M. Woydt and K. H. Habig, Wear, 162164, 220-28 (1993)

10) S. Sasaki, Junkatsu, 33, 620-28 (1988) [in Japanese].

11) T. Doi, "Kotaijunkatsu Handbook," Ed. by Y. Tsuya, Miyuki Shobo (1978) pp. 67-84 土肥 禎, “固体潤滑ハンドブック, ”津谷裕子編, 幸書房 (1978) pp. 67-84.

12) T. Ishikawa and T. Nagaoki, J. Jpn. Soc. Mech. Eng., 76, 1543-49 (1973) [in Japanese]. 